\title{
WT1 235-243 Peptide Vaccine
}

National Cancer Institute

\section{Source}

National Cancer Institute. WT1 235-243 Peptide Vaccine. NCI Thesaurus. Code C104734.

A synthetic peptide vaccine consisting of a HLA-A24-restricted human Wilms' Tumor protein-1 (WT 1) peptide comprised of amino acids 235 through 243, a MHC class Irestricted peptide, with potential immunomodulating and antitumor activities. Vaccination with WT 1 235-243 peptide may induce a WT 1-specific cytotoxic T-lymphocyte (CTL) response against WT 1 expressing cells, resulting in cell lysis and inhibition of cancer cell proliferation. WT 1, a zinc finger DNA-binding protein, is overexpressed in most types of leukemia and in a variety of solid cancers. 